\title{
ЛЕВЫЙ ЦЕНТРИЗМ В БОЛГАРИИ: ИСТОКИ И УСЛОВИЯ ФОРМИРОВАНИЯ
}

\section{М. В. Тортика}

Tортіка М. В. Лівий центризм у Болгарії: витоки і умови формування. У статті досліджені умови формування лівого центризму у Болгарії. Зокрема, розглядається специфіка розвитку Болгарського соціал-демократичного союзу, вивчається динаміка його взаємовідносин з Болгарською соціал-демократичною партією. Відокремлені основні етапи, характерні для раннього періоду політичної історії лівоцентристського руху. Водно проводиться аналіз політичної платформи болгарського центризму, оцінюється дуалістична природа його ідейно-політичної мотивації.

Ключові слова: Болгарія; центристська „лівиця”; лівий центризм; соціал-демократичний рух.

Тортика М. В. Левый центризм в Болгарии: истоки и условия формирования. В статье исследованы условия формирования левого центризма в Болгарии. В частности, рассматривается специфика развития Болгарского социал-демократического союза, изучается динамика его взаимоотношений с Болгарской социал-демократической партией БСДП. Выделены основные этапы, характерные для раннего периода политической истории левоцентристского движения. В то же время, проводится анализ политической платформы болгарского центризма, оценивается дуалистическая природа его идейно-политической мотивации.

Ключевые слова: Болгария; центристская «левица»; левый центризм; социал-демократическое движение.

Tortika M. V. Left centrism in Bulgaria: the genesis and formation conditions. The article studies the conditions of formation of left centrism in Bulgaria. Particularlyq it considers the specificity of the Bulgarian Social Democratic Union and studies the dynamics of its relations with the Bulgarian Social Democratic Party. The main stages, typical for the early period of the political history of the center-left movement, are separated. At the same time, the analysis of the political platform of the Bulgarian centrism is carried out and dualistic nature of its ideological motivation is estimated.

Keywords: Bulgaria; centrist left-wing; Left centrism; social democratic movement.

В советской и современной историографии (причем, как отечественной, так и зарубежной), левоцентристское движение в Болгарии, как правило, рассматривалось в парадигме политической истории начала XX ст. Однако именно предпосылки конца XIX ст. предопределили сам факт существования подобного направления и обусловили его реальное цивилизационное содержание.

В контексте историографического опыта второй половины XX - начала XXI ст. следует говорить об особой тенденции, в рамках которой данное движение рассматривалось исключительно как часть болгарского оппортунизма, т.е. без учета его организационной специфики и внутренней самобытности. Примером подобных взглядов являются работы А. Аврамова ${ }^{1}$, С. Георгиева (его исследование было написано позднее, но с близких идеологических позиций $)^{2}$, коллективная монография «Возникновение, развитие и закат оппортунизма в болгарском рабочем движении» ${ }^{3}$, исследования Т. Митева ${ }^{4}$, М. Исусова ${ }^{5}$ и др. Особое место в этом ряду специальных исследований занимает монография болгарского историка Й. Йотова «Центризм в болгарском социалистическом движении 1905 $1920 »^{6}$, которая была подготовлена, во-первых, на основе широкого документального материала и, во-вторых, подчеркивала самостоятельный характер данного движения. Иными словами, левый центризм презентовался в работе Й. Йотова как явление идейно близкое, но, в то же время, отнюдь не тождественное болгарской разновидности реформизма. В то же время автор сознательно не делал различий между западноевропейским и балканским (болгарским) вектором левого центризма, в этом смысле лишая его очевидной национальной и культурно-политической самобытности.

Итак, многие болгарские авторы, анализируя этапы внутреннего развития левоцентристского движения, игнорировали период его скрытого, латентного существования на рубеже XIX-XX ст. В этой связи сразу же следует отметить, что болгарская социал-де- 
мократия изначально не развивалась как однородное политическое явление. Собственно, после полулегальных встреч в Тырново и на Бузлудже в 1891 г. в ней сформировалось два центра: тырновский - Болгарская социал-демократическая партия (БСДП с Н. Габровским и Д. Благоевым во главе) и, чуть позже, софийский (1892 г.) - Болгарский социал-демократический союз (БСДС, лидерами которого стали Я. Сакызов, Е. Дабев и С. Мутафов*)7. Кроме того, сам БСДС также имел сложную структуру, включавшую в себя две автономные группы: севлиевскую в Болгарии и женевскую за границей.

Болгарский исследователь Т. Митев, размышляя об идейно-политической платформе БСДС, писал о некой «философии выживания», полагая, что вся дообъединительная стратегия Союза может трактоваться как скрытое приспособленчество группы популистов и карьеристов ${ }^{8}$ В этой связи особый интерес представляет тот факт, что болгарские социалисты в Женеве, большая часть из которых позднее встала на левоцентристские позиции, решительно выбрали именно платформу БСДС. Десятилетие спустя, то есть уже в процессе обособления «анархо-либеральной» оппозиции, Г. Бакалов, возвращаясь к полемике между представителями «Союза» и «Партии» (так он называл БСДП и БСДС), вспоминал, что причиной подобного выбора оказался более открытый политический курс «Союза» (ориентированный на привлечение «массового рабочего класса к социализму»), в то время как «Партия» рисковала остаться организацией «без рабочего движения».

Небезынтересно, что К. Раковский, в то время еще совсем молодой марксист, так же пытался обратить внимание Д. Благоева, центральной фигуры болгарского социалистического пространства, на особую «консервативную» (ремесленную) природу избирательного электората формирующейся партии. Фактически, именно центристы изначально поставили перед всем марксистским движением вопрос о характере социал-демократической организации как таковой, а именно: должна ли она представлять собой легальную социал-демократическую партию со всеми вытекающими из этого в парламентской стране ${ }^{10}$ последствиями или складываться как открытое социал-демократическое общество с просветительскими целями и пропагандистскими задачами.

По всей видимости, Д. Благоева мало устраивал как первый, так и второй вариант партийного строительства. В своей, впоследствии ставшей знаменитой, работе «Очерки истории социализма в Болгарии» он писал, что «партийцы» уже тогда, в конце XIX в., понимали значение партии как социал-демократической политической организации, подчеркивали ее роль «авангарда», «передового отряда рабочего движения», рассматривали ее как «...организованную военную силу рабочего класса...»" ${ }^{11}$. В сущности, с более широким абрисом будущей партийной организации его временно примирили только неожиданные общедемократические успехи 1892-1893 гг,, а также воспитательный характер избирательной социалистической пропаганды, способной повлиять, как он полагал, на классовое сознание пролетариата.

БСДС и, соответственно, принявшие его сторону будущие центристы, напротив, склонялись к концепции более открытой социал-демократической организации. Достаточно быстро «союзистами» был подготовлен проект партийного устава, который, тем не менее, опирался на ясно выраженные принципы классического марксизма ${ }^{12}$ и в этой связи предусматривал отказ от любых (пусть даже и временных) межпартийных компромиссов. Впрочем, особый параграф этого документа специально оговаривал, что данный запрет может быть преодолен в случае, если компромиссы обеспечат явную общепартийную «пользу» ${ }^{13}$. Таким образом, мысль о возможной целесообразности тактических общедемократических блоков проникла в недра мелкобуржуазной составляющей болгарской социал-демократии почти за восемь лет до знаменитой «каучуковой» резолюции К. Каутского, принятой Парижским конгрессом Второго Интернационала.

* В приведенном здесь документе (он представляет собой отчет К. Бозвелиева, направленный от имени всей социал-демократической партии Болгарии к членам действующего МСБ Второго Интернационала в июле 1901 г.) почему-то не упоминается К. Раковский. В то же время совершенно точно известно, что он занимал весьма авторитетное положение в Болгарском социал-демократическом союзе, с одной стороны, как лидер женевской группы, с другой - как один из его теоретиков. - См.: Възникване, развитие и залез на опортюнизма в българското работническо движение 1891-1948. София: Партиздат, 1986. - С. 29. 
Со временем противоречия нарастали. Косвенно, хотя и весьма своеобразно, они отразились в более поздних воспоминаниях X. Кабакчиева ${ }^{14}$. Удачно избежав упоминаний о полемике «союзистов» и «партийцев» (термины, которые в политической публицистике использовал Д. Благоев и которые часто встречаются в современной болгарской историографии), он все же не мог не сказать о собственном пребывании в Женеве. Попал он туда в последние годы XIX в., т.е. именно тогда, когда градус социал-демократических дискуссий находился в зените, подогреваемый политическими баталиями и личными эмоциями, выплескивающимися из каждой ресторации, каждого кафе или клуба ${ }^{15}$. Причем, существенное количество этой пассионарной, интеллектуальной и более или менее независимой в финансовом отношении публики составляли студенты всех мастей, а также политические эмигранты, в особенности из России и, частично, из Болгарии ${ }^{16}$.

Однако, если все упоминания о Женеве, которые встречаются в биографиях Г. Бакалова или К. Раковского, наполнены почтением и восхищением перед атмосферой этого города, перед масштабами наполнявшей его «социалистической жизни», то соответствующие страницы в воспоминаниях Х. Кабакчиева иначе как скудными да, пожалуй, еще и скучными, не назовешь. Болгарских студентов много, около ста, пишет Х. Кабакчиев, социалистов из них «два десятка». Ощущение такое, что в интерпретации именно этого автора вся кипучая полнота женевской жизни преломляется как-то глупо и ограниченно, временами почти опереточно.

Все становится на свои места, после того как Х. Кабакчиев уточняет, что в социалистической партии «Швейцарии немецкой... и особенно французской Швейцарии ...преобладало влияние оппортунистов...». «...Женева и Швейцария, - продолжает далее этот автор, - дали мне мало для осознания массового и революционного движения пролетариата в тогдашней капиталистической Европе...», а этот и только этот опыт может быть по-настоящему ценен для социалистической жизни Болгарии ${ }^{17}$. Таким образом, сразу становится понятно, что в таком контексте прямых упоминаний об особой роли женевской группы в воспоминаниях X. Кабакчиева не было и быть не могло.

Можно смело утверждать, что вплоть до 1894 г. в социал-демократическом движении Болгарии не существовало ни идейного, ни даже формального организационного единства. Однако, уже в первые годы осязаемой деятельности болгарских социалистических организаций (1891-1893 гг.) проявилась некоторая обособленность женевской группы (территориальная, культурно-политическая), которая позволяет рассматривать ее в качестве предтечи будущего центристского вектора в социал-демократическом движении страны.

В сложившейся ситуации надежд на объединение было немного. В то же время «свирепый террор Стамболова», как писал в «Очерках истории социализма...» Д. Благоев, довольно настойчиво провоцировал потенциальное объединение социал-демократических групп. В результате, начальный этап раннесоциалистической деятельности БСДП завершился незапланированной встречей С. Мутафова и Д. Благоева в Софии ${ }^{18}$. Затем последовали переговоры, целью которых было объединение обеих социалистических организаций. Переговоры также прошли неожиданно успешно и завершились учредительным конгрессом (1894) теперь уже единой Болгарской рабочей социал-демократической партии (БРСДП). Так было положено начало следующего этапа в развитии социал-демократического движения страны, для которого характерно уточнение конкретной политической программы правой ветви болгарского социализма. На этот раз конкуренция возникла между внутрипартийными течениями, которые олицетворяли такие крупные общественно-политические и социал-демократические деятели, как Н. Габровский и Я. Сакызов.

Надо сказать, что Н. Габровский стоял у истоков болгарского социалистического движения. Он, по всей видимости, был единственным болгарским социалистом, побывавшим на Парижском учредительном конгрессе Второго Интернационала в 1889 г. Эмоциональный, темпераментный, склонный к аффектам и политической агитации, он предстает в воспоминаниях Г. Бакалова молодым человеком с длинными, свисающими на лоб волосами, которые он то и дело поправляет нервной рукой. Позднее Д. Благоев несколько иронично замечал, что Н. Габровского отличало характерное смешение энтузиазма «...c неясностью социалистической мысли ${ }^{19}$. Однако сам Г. Бакалов, даже спустя не один десяток лет, писал о Н. Габровском все с тем же уважением и личной симпатией ${ }^{20}$. Впрочем, 
даже в контексте этих небольших по объему воспоминаний описание Н. Габровского соответствует более типу народника, чем образу социал-демократа. В результате «теоретиком» будущей тесно-социалистической фракции БРСДП стал Д. Благоев, а его широко-социалистическим оппонентом оказался не беспокойный и импульсивный Н. Габровский, а «сентиментальный социалист» Я. Сакызов.

То, что между Я. Сакызовым и Н. Габровским обнаруживались принципиальные идейные расхождения, отмечал и сам Я. Сакызов. Так, последний, судя по воспоминаниям Д. Благоева, еще в 1892 г. объединял политические взгляды Д. Благоева и Н. Габровского, противопоставляя им свое восприятие социализма как некоего комплекса «идеальных чувств», «желаний» и «условий» ${ }^{21}$. Впрочем, то «прекраснодушие», в котором Д. Благоев часто упрекал Я. Сакызова, никак не помешало ему вполне по-деловому объединить вокруг себя идейно близкую группу социалистов. В результате, уже в 1896 г. в личном письме к Д. Благоеву Н. Габровский признавал, что силы его слабеют, в то время как он явно наблюдает «восхождение» сакызовской ветви широкого социализма ${ }^{22}$.

Итак, с новой силой полемика внутри БРСДП развернулась между 1895-1897 гг., а уже в 1898 г. впервые был поставлен вопрос о партийной дисциплине. В этой связи (анализируя практику избирательных компромиссов, характерную как для Я. Сакызова, так и Н. Габровского) Д. Благоев писал об утрате влияния социализма в его естественной среде и о его превращении «в мелкобуржуазный радикал-социализм». Основным компонентом расширения избирательной платформы партии Д. Благоев считал «крестьянский» вопрос, в чрезмерной эксплуатации которого упрекал Н. Габровского. Параллельно он критиковал идейное направление, которое олицетворял Я. Сакызов, называя центрального реформиста БРСДП не иначе как «социалиствующий буржуа» ${ }^{23}$. Тем самым он намекал на деятельность сакызовцев в мелкобуржуазной среде и на присущее им увлечение либеральнодемократическим реформаторством.

Анализ внутрипартийных разногласий, интерпретируемых Д. Благоевым, не исчерпывался противопоставлением взглядов Я. Сакызова и Н. Габровского. Собственно, в приведенную выше полемику прокрестьянских и околобуржуазных течений болгарского (используем здесь термин самого Благоева) «оппортунизма», совершенно неожиданно вклинивалась обособленная позиция теперь уже бывшего «женевца» К. Раковского ${ }^{24}$. Так, в издании «Социалист» за номером 76 появилась его статья, посвященная крестьянскому вопросу. В ней автор отмечал, что само по себе требование политической поддержки крестьянских интересов никак не противоречит генеральным принципам БРСДП. В то же время он утверждал, что крестьянский вопрос вполне совместим с требованием демократических реформ. Таким образом, в этой статье явно присутствовал более гибкий и вместе с тем достаточно «широкий» подход к политической платформе БРСДП. Собственно, сам К. Раковский обосновывал свою социалистическую толерантность местными условиями, которые он называл «родовыми муками» экономического роста Болгарии. К тому же, по мнению автора, болгарская социал-демократия все еще переживала начальный этап своего идейного и организационного развития. Итак, на этот раз элемент будущей центристской идеологии заявил о себе в рамках полемики представителей правого течения БРСДП. Пытаясь выровнять отношение к внутрипартийным линиям Н. Габровского и Я. Сакызова, К. Раковский сделал несомненную заявку на примиренческий характер своих политических (пока еще не вполне центристских) взглядов и указал на возможную лояльность своих единомышленников к правосоциалистическому крылу БРСДП.

Однако, как позднее отмечал Д. Благоев, усиление правой фракции БРСДП не могло не нарушить баланса внутрипартийных взаимоотношений. В результате партия оказалась в той безысходной ситуации, разрешением которой могла стать только жизнь или смерть одного из этих течений.

В конечном счете, более аморфные правосоциалистические представления (объединение «всех производящих слоев») обрели идейный фундамент в реформистской концепции

\footnotetext{
* Имели место также и упреки личного характера. В частности, Д. Благоев утверждал, что Я. Сакызов не только «прожектер» и «фантазер», но еще и бездельник, который «привык к тому, чтобы его прожекты... возлагали на себя другие...». - См.: Благоев Д. Принос към историята на социализма в България // Благоев Д. Съчинения. - София: Изд-во на БКП, 1960. - Т. 11. - С. 307.
} 
западноевропейского социализма. Последнее наглядно продемонстрировало начавшее выходить осенью 1900 г. издание «Общо дело», задачей которого стало обоснование теоретических взглядов самого Я. Сакызова и его единомышленников. Задуманное вначале как литературное приложение к центральному партийному органу, оно практически сразу приняло форму самостоятельного двухнедельного политического журнала ${ }^{25}$. Впрочем, как совершенно справедливо заметил в 1906 г. Д. Благоев, анализируя все более ускорявшийся темп межпартийных идеологических и организационных разногласий, на самом деле важно даже не то, как это издание появилось, а то, какое содержание оно в себе несло. Суть поднимаемых журналом проблем касалась насущных демократических потребностей, причем как в «торгово-индустриальной» среде, так и в «мещанско-ремесленных» слоях более традиционного болгарского общества. Все они, по мнению Я. Сакызова, имели право на «свободу и законность», все они фигурировали на страницах «Общо дело», и все они, с точки зрения Д. Благоева, делали это издание не просто далеким, но абсолютно «не имеющим ничего общего с социализмом» ${ }^{26}$. Так было положено начало третьему и последнему этапу раннего периода истории социал-демократического движения Болгарии.

Впервые на официальном уровне расхождения между ортодоксальным и реформистским направлениями были зафиксированы в ходе Пятого (Парижского) 1900 г. конгресса Второго Интернационала, на котором в качестве представителя БРСДП в очередной раз присутствовал К. Раковский ${ }^{27}$.

Суть проблемы заключалась в том, что уже в последнем десятилетии XIX в. уверенность социалистов в близкой реализации социал-демократических перспектив имела вполне рациональный и достаточно осознанный характер. Так, А. Бебель, выступая на партийном съезде еще в 1891 г., подчеркивал, что большинство из присутствующих в Эрфурте почти наверняка доживут до окончательной победы классовой борьбы пролетариата ${ }^{28}$. На рубеже XIX-XX вв. подобные перспективы стали подпитываться очередным ускорением роста производства и все увеличивающимися темпами индустриализации ${ }^{29}$. В результате, у некоторых представителей международной социал-демократии начало формироваться мнение о неадекватности отдельных идейных положений марксизма экономическим, а возможно, и политическим реалиям довоенной Европы. В количественном отношении этот процесс выражался следующим образом: с 1859 г. по 1914 г. общемировое индустриальное производство увеличилось в 7 раз, в то время как в России и в США оно же увеличилось в 12 раз. Особенно значимыми оказались цифры, фиксировавшие количественный рост членов рабочих профсоюзов. Так, например, численность французских профсоюзов выросла с 420 тыс. человек (в 1895 г.) до миллиона и больше в 1913 г. и т.д. ${ }^{30}$.

Такой рост потенциальной электоральной базы социалистов естественным образом поставил их перед вопросом о детерминизме (в противовес радикализму) в политической практике марксизма. В результате с 1896 г. в печати стали появляться фрагменты идеологически обновленной концепции Э. Бернштейна, человека, в личном плане настолько близкого к Ф. Энгельсу, что последний назначил его, наравне с А. Бебелем, своим душеприказчиком.

Собственно, уже в 1896 г. Э. Бернштен начинает публично излагать свои взгляды, следствием чего становится публикация цикла статей под общим названием «Проблемы социализма и задачи социал-демократии» (см. так же его работы: «Условия возможности социализма и задачи социал-демократии», «Массовая политическая стачка и политическое положение германской социал-демократии», «Очерки из истории и теории социализма», «Реалистический и идеологический момент в социализме» и т.д. $)^{31}$.

Сама идеологическая система, предложенная Э. Бернштейном, состояла как бы из двух частей: теоретической и практической. Теоретическая часть представляла собой анализ основных положений научного социализма, пересмотр которых мог, по крайней мере отчасти, привести к изменению философской основы указанной концепции. Главы, посвященные тактическим вопросам, определяли основные задачи социал-демократии и методы их решения. Их корректировка, по мнению Э. Бернштейна, должна была несколько осовременить хрестоматийный характер марксизма, теоретические положения которого (в силу их внутренней замкнутости) все чаще оказывались причиной не предусмотренных К. Марксом политических рефлексий. 
Новое прочтение философского фундамента марксизма, предложенное Э. Бернштейном, не могло не вызвать мощного отклика в кругу европейской социал-демократии. В частности, одним из первых, наравне с К. Каутским ${ }^{32}$ и Р. Люксембург ${ }^{33}$, на него отреагировал Г.В. Плеханов. Энергично возражая Э. Бернштейну в «Die Neue Zeit» ${ }^{34}$, он, по сути дела, прямо обвинил Бернштейна в том, что, живя бок о бок с Ф. Энгельсом много лет, он «...мог обеими руками черпать из богатой сокровищницы великого мыслителя..., но так и не понял его философии» ${ }^{35}$. Итогом публичной полемики Г.В. Плеханова с Э. Бернштейном стал объемный сборник произведений корифея российского марксизма («Критика наших критиков»), опубликованный в 1906 г. под псевдонимом Н. Бельтов.

Резкий тон противников Э. Бернштейна косвенно подтверждал реальность обозначенных данным автором проблем, вне всякого сомнения, существовавших в практике европейской социал-демократии, вступавшей в пору политической зрелости. Подобный подход к теории социализма обусловил и значительно усилил практическую часть концепции Э. Бернштейна. Поднимая вопрос о конечной цели классовой борьбы, он утверждал, что в глобальном общесоциалистическом плане отказа от подобной перспективы нет и быть не может. Однако положение данной цели должно быть подвижным, поскольку, закрепляясь идеологически, она может стать «...помехою для действительного теоретического и практического преуспевания движения» ${ }^{36}$. Только реальные политические и экономические условия могут стать основой социалистической деятельности, «...мы должны считаться с конкретными фактами..., если не желаем наделать грубых ошибок», - подчеркивал Бернштейн. Таким образом, в практическом выражении его концепцию можно рассматривать как синтез тактики быстрого политического реагирования с теорией, утверждающей принцип новых социальных отношений.

Как известно, в качестве официальной марксистской идеологии концепция Э. Бернштейна была отвергнута решительно и бесповоротно. Тем не менее, избирательные успехи некоторых социалистических партий, опыт А. Мильерана ${ }^{37}$, Г. Фольмара ${ }^{38}$, Ф. Турати ${ }^{39}$ подтверждали политическую перспективность ревизионистских концепций. Достаточно сказать, что только в одной маленькой Болгарии к 1899 г. социал-демократы получили шесть мест в парламенте, вследствие чего Я. Сакызов публично ратовал за изменение парламентской тактики БРСДП.

Следствием указанных противоречий стало принятие Парижским конгрессом (1900) Второго Интернационала «каучуковой резолюции» К. Каутского. Официально эта резолюция отрицала путь к завоеванию власти пролетариатом через буржуазные правительства, однако одновременно не исключала возможности вхождения социалистов в коалиционные правительства в соответствующих политических условиях и с согласия всей партии.

С точки зрения поставленных в данном исследовании цивилизационных задач, весьма интересно, как на подобные решение прореагировал близкий болгарскому центризму социал-демократ К. Раковский. Вслед за своим другом и учителем Г.В. Плехановым, под особым влиянием которого он в это время находился ${ }^{40}$, К. Раковский категорически отмежевался от концепции идейно-политической ревизии, предложенной Э. Бернштейном. В то же время, анализируя в «Искре» итоги социалистического форума в Париже, он, peализуя присущий центризму культурно-политический дуализм, подчеркивал, что не стоит пренебрегать «...ни единой, даже незначительной реформой, способной и в современном обществе улучшить положение рабочих...» ${ }^{41}$.

Между тем, в свете приведенных выше идейных разногласий, положение внутри БРСДП стремительно ухудшалось. В частности, конгрессы в Плевне (1901 г.) и в Тырново (1902 г.), задачей которых было подтверждение «чисто пролетарского характера БРСДП», показали, что в идеологический конфликт оказалась втянутой практически вся партия ${ }^{42}$. Наконец, к марту 1903 г. стало ясно, что официальный раскол БРСДП - лишь вопрос времени.

В сложившейся ситуации значительную роль в формировании широко-социалистической платформы БРСДП сыграл теоретический журнал Я. Сакызова «Общо дело» (1900). Сам Я. Сакызов позже подчеркивал, что источником его политического и литературного вдохновения был пример германской социал-демократии. Фактически это стало одним из его наиболее весомых аргументов, оправдывавших существование подобного изда- 
ния. Поскольку без него, утверждал редактор «Общо дело», восприятие «живых проявлений болгарской жизни» было бы неполным, особенно в условиях, когда ни «Работнически вестник», ни «Ново време» не отражают «умственных брожений», характерных для «западных» или тем более для отечественных социалистов ${ }^{43}$. Впрочем, Д. Благоев был склонен объяснять развернувшуюся вокруг данного издания полемику «общедельскими интригами» ${ }^{44}$, а саму сакызовскую группу называл не иначе как «оппортунистической» и «буржуазно-демократической» ${ }^{45}$. Таким образом, еще до раскола 1903 г. социалистический характер правой оппозиции был поставлен под сомнение, а сама она определялась теми идеологическими штампами ${ }^{46}$, которые позже стали постоянным речитативом любых публичных выступлений, равно как и официальной переписки тесно-социалистического ЦК с руководством Второго Интернационала.

Первоначально раскол прошел по линии Центрального Комитета, в котором Я. Сакызов и Е. Дабев объединились против левого крыла внешне нейтрального внутрипартийного руководства. Затем последовало дробление Софийской партийной организации - этого, как образно выразился Д. Благоев, «гнезда общедельского интриганства» ${ }^{47}$. В результате, с выходом 50 человек из софийской партийной организации она фактически перестала существовать, создавая повод для «формального кризиса партии и ее раскола» ${ }^{48}$.

22 марта 1903 г. левым большинством ЦК был обнародован известный циркуляр № 399, сутью которого стал вопрос о форме дальнейшего существования «общедельства» ${ }^{49}$. В течение нескольких последующих месяцев шел процесс самоопределения местных организаций, который завершился двумя июльскими конгрессами, оборвавшими номинально все еще сохранявшееся партийное единство. Один состоялся в Руссе 19-25 июля - это был Х конгресс БРСДП и, соответственно, первый для БРСДП (тесных социалистов $)^{50}$. Второй был созван 13-18 июля в Софии, став первым учредительным конгрессом БРСДП (широких социалистов), также $\mathrm{X}$ по прежней нумерации ${ }^{51}$. Таким образом, формально третий и последний этап раннесоциалистического движения в Болгарии был завершен летом 1903 г. В то же время до открытого проявления «анархо-либеральных» тенденций внутри БРСДП (т.с.) все еще оставалось не менее двух лет. Кроме того, в августе 1904 г. должен был состояться Амстердамский конгресс, объединительной резолюции которого только предстояло отразиться в кривом зеркале болгарских внутрипартийных дискуссий.

Нерешенный в 1900 г. вопрос о социалистической тактике, явное усиление реформистских течений в среде немецкой, французской, русской, болгарской и т.д. социал-демократий - все это делало разговор о единстве социалистических сил темой болезненной, но насущной. Фактически была осознана необходимость идейного возврата к истокам политических противоречий, экономический и социально-политический фундамент которых обеспечивал стабильность правой внутрипартийной оппозиции. В этой связи в апреле 1903 г. В. Коларов писал в «Работнически вестник», что предстоящий раскол необходимо признать и отнестись к нему хладнокровно и трезво, без причитаний об «иллюзорном» партийном единстве ${ }^{52}$. Только тогда, подчеркивал он, можно будет говорить о сути разногласий без упоминаний о «личных амбициях... и соперничестве», но на основании той теории, которая носит ярко выраженный «пролетарский характер» ${ }^{53}$.

Впрочем, как представляется, современный взгляд на истоки подобных концептуальных противоречий должен быть не только шире (последнее очевидно), но и глубже. Во-первых, как уже отмечалось ранее, Э. Бернштейн полагал, что классовая диктатура в странах с устойчивой парламентской системой есть «политический атавизм», который все более и более не соответствует современным методам западноевропейской политической борьбы. В то же время, анализируя цивилизационный фундамент восточноевропейских (в настоящем контексте, болгарских) социал-демократических разногласий, следует заметить, что как по качеству, так и по количеству (отсутствие соответствующей исторической традиции) болгарский парламентаризм оказался трудно сопоставим с демократическими институтами Западной Европы. Так, например, болгарская государственная система действительно гарантировала существование марксистской партии как партии легальной и парламентской. Тем не менее, как политический механизм, она, в первую очередь, представляла собой дополнительный фактор государственного равновесия, необходимый в условиях сложного дуализма княжеско-партийного руководства страной. 
Далее, в качестве следующего фактора социал-демократических противоречий, следует назвать многовекторный цивилизационный контекст балканского региона, обусловивший разницу в культурно-политической ориентации реформистской и ортодоксальной фракций БРСДП. Собственно, в сложившейся ситуации сложно говорить о реальном значении реформ, поверхностная реализация которых была связана с характером крестьянского менталитета, не настроенного на принятие активной трансформации традиционного состояния культуры. Этот момент удачно характеризует «Воззвание» представителей сельской интеллигенции, обращенное к болгарским крестьянам в 1899 г. (По материалам Гришиной Р.П.): «.... мы не знаем новых машин, больших и малых... Мы действуем по-старому, ветхозаветно: стараемся, пыжимся и при явной бесплодности наших усилий, при потерянном здоровье и разбитой жизни. Говорим: «наши отцы не умирали от голода, и мы не помрем.... ${ }^{54}$. Безусловно, до 1917 г. руководство большинства марксистских партий стремилось ориентироваться, в основном, на рабочие массы населения и не считало крестьянство значимой частью своего электората. Однако, и это необходимо подчеркнуть особо, несколько поколений городской жизни не смогли существенно изменить крестьянскую специфику рабочего менталитета в Болгарии. Следовательно, болгарский социализм был вынужден тактически приспосабливаться к специфике местных культурно-политических условий.

Вариантов достаточно предсказуемой политической мимикрии было несколько, один - широкий - избрал Я. Сакызов ${ }^{55}$. Теоретическая программа данного течения ориентировалась на платформу, характерную для европейского реформизма, но при этом была вынуждена учитывать местные экономические, а, главное, социально-политические особенности, двигаясь от «рабочей аристократии» промышленно развитых европейских стран к мелкобуржуазной среде аграрных государств Восточной Европы.

В свою очередь, говоря о стратегии болгарского ортодоксального марксизма, следует отметить, что данное течение, напротив, было ближе к платформе традиционалистских фракций, более характерных для политического пространства стран Восточной Европы. Подобные тенденции обнаруживались, во-первых, в идеализации потенциальных политических перспектив и, во-вторых, в характерных элементах этнокультурного традиционализма, который существовал на основе идейного синтеза «спиритуалистического марксизма» и соответствующей национальной ментальности. Таким образом, данная социалистическая модель также оказывалась одним из способов политического приспособленчества, использование которого примиряло классический марксизм с социальными условиями Болгарии.

Конечно, политический детерминизм Второго Интернационала подталкивал его руководство к пропаганде принципов организационного сближения, несомненно востребованных в условиях роста милитаристской активности ряда европейских государств. В подобной ситуации наиболее известные западные теоретики марксизма не хотели признавать той культурно-политической пропасти, которая отныне рассекала международное рабочее движение и, в частности, пролегла между обеими фракциями болгарского социализма. Примером подобного прагматичного подхода стала точка зрения одного из наиболее крупных представителей будущего центристского вектора Интернационала II К. Каутского, который еще за год до Парижского конгресса подчеркивал: «В нашей партии всегда существовали разногласия - разногласия личного, местного, профессионального и теоретического характера. Молодой и горячий думает иначе, чем старый и рассудительный; баварец - иначе, чем саксонец, а тот иначе, чем гамбуржец.... Такие различия не только неизбежны, но даже необходимы, чтобы не замерла внутренняя духовная жизнь партии. Но эта последняя - армия борцов, а не клуб для обмена мыслями; обнаруживающиеся в ней противоречия не должны идти настолько далеко, чтобы исчезла самая возможность плодотворной совместной работы.... ${ }^{56}$.

Таким образом, еще до раскола 1903 г. возникла некая обобщающая социал-демократическая тенденция, ведущая к поиску и поддержке сторонников партийного единства, способных, несмотря на присущий им демократизм и широту мышления, строго придерживаться ортодоксальных принципов «классической» марксистской идеологии. В Болгарии, накануне Амстердамского конгресса, эта потребность осложнилась необходимостью своеобразного интеллектуального транзита, существовавшего (в контексте объ- 
единительной тактики Международного социалистического бюро) между западничеством «общедельства» и нигилизмом тесного социализма. Иначе говоря, появилась потребность в деятельности не просто убежденных марксистов, но интеллектуалов, способных совмещать европейскую социал-демократическую модель с элементами национального болгарского самосознания. Накануне Амстердамского конгресса в Болгарии уже существовали все предпосылки для формирования левоцентристской фракции и, более того, были ясны принципиальные задачи будущего движения, которые, по всей видимости, следует обозначить, с одной стороны, как посреднические (культурно-политические), а с другой - как организационные (объединительные).

${ }^{1}$ Аврамов А. Политическата стратегия и тактика на БКП (1903-1923). - София: Партиздат, 1974. $-327 \mathrm{c}$

${ }^{2}$ Георгиев С. Общоделският опортюнизъм. Облик и съдба. 1903-1912. - София: Партиздат, 1985. $-174 \mathrm{c}$.

${ }^{3}$ Възникване, развитие и залез на опортюнизма в българското работническо движение $1891-$ 1948. - София: Партиздат, 1986. - 689 с

${ }^{4}$ Митев T. Широкият социализъм 1892-1900. - София: Университетско издателство «Климент Охридски», 1989. - 168 с.

${ }^{5}$ Исусов М. Революционното профсъюзно движение в България (1903-1912) / Кабинет за история на профсъюзното движение в България. - София: Профиздат, Изд-во на ЦС на профсъюзите, 1962. -229 с

${ }^{6}$ Йотов Й. Центризмът в българското социалистимческо движение 1905-1920. - София: Изд-во на БКП, 1969. - 423 с.

${ }^{7}$ Bozwelieff Counstantin 24.07.1901 // Fondazione Feltrinelli. - Repertorio del materiali del BSI. Bulgaria. - № 182-185, 175. - № protocollo 891 .

${ }^{8}$ Митев T. Широкият социализъм 1892-1900. - София: Университетско издателство «Климент Охридски», 1989. - С. 35.

${ }^{9}$ Бакалов Г. Партия или котерия // Интелигенски индивидуализъм или интелигенска диктатура? - София: Печатница Гавазов и Чомонев, 1905. - С. 15.

10 Понятно, что в данном случае, речь шла о возможной политической перспективе, но отнюдь не о парламентской практике «стамболовистского террора» (как писал позднее об этом времени Д. Благоев).

${ }^{11}$ Благоев Д. Принос към историята на социализма в България // Благоев Д. Съчинения. - София: Изд-во на БКП, 1960. - Т. 11. - С. 153.

12 В данном контексте определение «классический марксизм» тождественно социально-экономической и политической логике К. Маркса, т.е. формально логике, рожденной из наблюдений за процессами, протекающими в раннекапиталистических обществах.

${ }_{13}$ Възникване, развитие и залез на опортюнизма в българското работническо движение $1891-$ 1948. - София: Партиздат, 1986. - С. 26.

${ }^{14}$ Кабакчиев Христо - представитель болгарского социал-демократического движения, с 1903 г. член партии БРСДП (т.с.), в 1905 г. член ЦК партии тесных социалистов.

${ }^{15}$ См. дела Департамента полиции о революционной деятельности в Цюрихе и Женеве // Государственный архив Российской Федерации (далее ГАРФ), ф. 102, оп. 180, ед. хр. 47; ф. 102, оп. 186, ед. хр. 47: Т. 3, Т. 4; ГАРФ, ф. 102, оп. 232, ед. хр. 1075 и др.

${ }^{16}$ Переписка с Департаментом полиции и Бессарабским Главным жандармским управлением по личному составу и выяснению личности русских подданных, проживающих за границей // ГАРФ, ф. 505, оп. 1, ед. хр. 123.

${ }^{17}$ Кабакчиев Х. Спомени. - София: Изд-во на БКП, 1956. - С. 27-29.

${ }^{18}$ Благоев Д. Принос към историята на социализма в България // Благоев Д. Съчинения. - София: Изд-во на БКП, 1960. - Т. 11. - С. 226.

19 Там же. - C. 122.

${ }^{20}$ Бакалов Г. Никола Габровски, последният от старата гвардия // Бакалов Г. Избрани произведения. - София: Български писател, 1964. - Т. 4. - С. 279-284.

${ }^{21}$ Благоев Д. Принос към историята на социализма в България // Благоев Д. Съчинения. - София: Изд-во на БКП, 1960. - Т. 11. - С. 147.

${ }_{22}$ Митев T. Широкият социализъм 1892-1900. - София: Университетско издателство «Климент Охридски», 1989. - С. 41.

${ }_{23}^{23}$ Благоев Д. Принос към историята на социализма в България // Благоев Д. Съчинения. - София: Изд-во на БКП, 1960. - Т. 11. - С. 309.

${ }^{24}$ К этому времени партийная популярность К. Раковского выросла до масштабов его официального представительства на Цюрихском конгрессе Второго Интернационала. - См.: Международный 
социалистический конгресс в Париже // Искра. - 1900. - № 1 (декабрь). Данный факт, в противовес точке зрения Л.И. Зубока. См.: История Второго Интернационала / Под ред. Л.И. Зубока. - М.: Наука, 1965. - Т. 1. - 379 с., подтверждают такие болгарские историки, как А. Веков, Ж. Дамянова и Ф. Панайотов. Кроме того, в 1896 г. К. Раковский еще раз представлял БРСДП, теперь уже на Лондонском конгрессе Интернационала II. - См.: Международный социалистический конгресс в Лондоне 1896 г. - Б. м.: Типография группы рабочих - революционеров, 1896. - 88 с.; Раковский Х.Г. Автобиография // Энциклопедический словарь Гранат: Деятели СССР и Революционного движения России. - М., 1989. - С. 169-187; Писмо от К. Раковски до семейството му // Централен държавен архив на Република България (далее ЦДА на РБ), ф. 156, оп. 1, ед. хр. 277, л. 4. Его коллегой по Лондонскому конгрессу оказался еще один будущий центрист - Г. Бакалов. - См.: Георги Бакалов: живот и дейност. - София: Изд-во на Българската академия на науките, 1989. - С. 9.

${ }^{25}$ Писмо от Я. Сакъзов до К. Раковски // ЦДА на РБ, ф. 156, оп. 1, ед. хр. 465.

${ }^{26}$ Благоев Д. Принос към историята на социализма в България // Благоев Д. Съчинения. - София: Изд-во на БКП, 1960. - Т. 11. - С. 448-449.

${ }^{27}$ Международный социалистический конгресс в Париже // Искра. - 1900. - № 1 (декабрь).

${ }^{28}$ Интересно, что данная мысль имела большое значение и для Г. Бакалова, который (спустя некоторое время после смерти А. Бебеля) также подчеркивал, что социал-демократия стоит на пороге своих самых смелых ожиданий. - См.: Бакалов Г. Спорните въпроси на социалистическата тактика. - София: Знание, Б. г. - 60 с.

29 Так, например, Д. Благоев называл 1901 г. годом индустриального подъема страны.

${ }^{30}$ Българските социалдемократи и Международното социалистическо бюро. Кореспонденция 1900-1914 гг. / Съставители Кънева-Дамянова Ж., Дюмон П. - София: МИКОМ, 1996. - С. 4.

${ }^{31}$ См.: Бернштейн Э. Проблемы социализма и задачи социал-демократии / Пер. с нем. К. Бутковского. - М.: Изд. Ефимова, 1901. - 360 с.; Его же. Очерки из истории и теории социализма. - СПб.: Тип. Колпинского, 1902 - 400 с.; Его же. Реалистический и идеалистический моменты в социализме. - Б.м.: Изд. Козмана, Б. г. - 32 с.; Его же. Социальные проблемы (Условия возможности социализма и задачи социал-демократии). - СПб.: Слово, 1906. - 266 с.; Его же. Массовая политическая стачка и политическое положение германской социал-демократии. - Б. м.: Тип. А.Г. Розена, 1906. -63 с.

${ }^{32}$ Каутский К. К критике теории и практики марксизма («Антибернштейн»). - М.: УРСС, 2003. $-304 \mathrm{c}$

${ }^{33}$ См.: Люксембург Р. Реформа или революция. - Петроград: Издание Петроградского совета рабочих и красноармейских депутатов, 1919. - 108 с.; Ее же. Коалиционная политика или классовая борьба. - М.: Красная новь, 1923. - 118 с.

34 “Die Neue Zeit” (“Новое время”) - марксистский журнал социал-демократической партии Германии (СДПГ), выходил под непосредственной редакцией К. Каутского.

${ }^{35}$ Плеханов Г.В. Бернштейн и материализм // Плеханов Г.В. Сочинения. - М.: Госиздат, 1923. T. 11. - C. 12 .

${ }^{36}$ Бернштейн Э. Социальные проблемы (Условия возможности социализма и задачи социал-демократии). - СПб.: Слово, 1906. - С. 219.

${ }^{37}$ А. Мильеран (1859-1943) - французский социалист, вступил в правительство П. ВальдекаРуссо, создавая тем самым знаменитый прецедент социалистической тактики, известный как «министериализм».

${ }^{38} \Gamma$. Фольмар (1850-1922) - правый баварский социал-демократ, депутат рейхстага из Мюнхена.

${ }^{39}$ Ф. Турати (27.11.1857-30.03.1932) - итальянский политический деятель, публицист, идеолог итальянского реформизма.

${ }^{40}$ Иллюстрацией дружеских взаимоотношений К. Раковского и Г.В. Плеханова могут служить фрагменты их личной переписки, сохранившиеся в Центральном государственном архиве республики Болгария. - См.: Писмо от Г.В. Плеханов до К. Раковски // ЦДА на РБ, ф. 156, оп. 1, ед. хр. 448, л. 2.

${ }^{41}$ Международный социалистический конгресс в Париже // Искра. - 1900. - № 1 (декабрь).

${ }^{42}$ Благоев Д. Принос към историята на социализма в България // Благоев Д. Съчинения. - София: Изд-во на БКП, 1960. - Т. 11. - С. 472, 547; Милев Й. Спомени на стари партийни дейци за живота и дейността на софийската организация // ЦДА на РБ, сп. № 1187, л. 2.

${ }_{43}$ Бужашки Е. Д. Благоев и победата на марксизма в българското социалистическо движение 1885-1903. - София: Изд-во на БКП, 1960. - С. 325.

${ }^{44}$ Здесь и далее цитаты приводятся с особенностями авторского правописания.

${ }^{45}$ Надо сказать, что были и более «поэтические» эпитеты, сопоставляющие деятельность внутрипартийной оппозиции с образом червя, разъедающего тело партии. - См.: Благоев Д. Принос към историята на социализма в България // Благоев Д. Съчинения. - София: Изд-во на БКП, 1960. - Т. 11. - C. 552.

${ }^{46} \mathrm{C}$ эпитетами Д. Благоев обращался легко, в частности, характеризуя тактику классового сотрудничества, он писал, что речь идет о «...сотрудничестве всяческих дьяволов и вельзевулов буржуазии...». - См.: Благоев Д. Опортюнизъм или социализъм // Благоев Д. За партийното единство и партийната дисциплина. - София: Изд-во на БКП, 1958. - С. 40. 
${ }^{47}$ Благоев Д. Принос към историята на социализма в България // Благоев Д. Съчинения. - София: Изд-во на БКП, 1960. - Т. 11. - С. 554.

${ }^{48}$ Благоев Д. Принос към историята на социализма в България // Благоев Д. Съчинения. - София: Изд-во на БКП, 1960. - Т. 11. - С. 472, 554; Коларов В. Партийният кризи // Коларов В. Избрани произведения. - София: Изд-во на БКП, 1954. - Т. 1. - С. 1-5.

49 Окрьжно № 399 от марксистското мнозинство в ЦК на БРСДП - Д. Благоев, Г. Кирков и Н. Харлаков, до партийните организации за разногласията в партията и разцеплението в ЦК и Софийската организация // Българска комунистическа партия. Документи на централните ръководни органи 1900-1903. - София: Партизда, 1974. - Т. 2. - С. 504-521.

50 Делирадев П. Преди 50 години. Из спомените ми за Русеннския конгресс // ЦДА на РБ. Сп. № 532.

${ }^{51}$ Писмо от Я. Сакъзов до К. Раковски // ЦДА на РБ, ф. 156, оп. 1, ед. хр. 465, л. 2; Окръжно от ЦК БРСДП до месните организации // ЦДА на РБ, ф. 205, оп. 1, ед. хр. 3, л. 1.

52 Подробнее о партийном кризисе и утрате единства БРСДП см.: Коларов В. Единство и самокритика // Коларов В. Избрани произведения. - София: Изд-во на БКП, 1954. - Т. 1. - С. 6-10.

${ }^{53}$ Коларов В. Партийният кризи // Коларов В. Избрани произведения. - София: Изд-во на БКП, 1954. - T. 1. - С. 1-5.

${ }^{54}$ Гришина Р.П. Лики модернизации в Болгарии (бег трусцой по пересеченной местности) / Cерия «Человек на Балканах». - М.: Институт славяноведения РАН, 2008. - С. 80-81.

${ }^{55}$ Сакъзов Я. Тревога за призраци (нашето отстъпничество или тяхното недомыслие). - София: Б. и., 1991. -96 с.

${ }_{56}^{5}$ Каутский К. К критике теории и практики марксизма («Антибернштейн»). - М.: УРСС, 2003. - C. 26-27. 